\title{
МОНГОЛ УЛСАД ТӨВЛӨРЛИЙГ СААРУУЛАХ АСУУДАЛ
}

\author{
1 Л.Энхтайван, ${ }^{2}$ Л.Ариунаа \\ 1 “Эдийн засаг, санхүугийн бодлогын судалгааны төв” ТББ-ын тэргүүн \\ 2 Удирдлагын Академийн Эдийн засаг, санхүугийн удирдлагын профрессорын багийн ахлагч, \\ aruka_lkhagva@yahoo.com
}

\begin{abstract}
In general decentralization is connected with the transfer of responsibilities for planning, management, resource raising and allocation from the central government to the lower levels of government. In particular fiscal decentralization means that local authorities become responsible for the expenditure and revenue assignment. From the economic and political science perspectives fiscal decentralization will improve resource allocation and accountability, which results in an efficient and effective supply of public goods and support private markets.

In last decade Mongolia has introduced a number of decentralization measures, which followed a top dawn approach and were slowly implemented without any integrated decentralization strategy. Currently Mongolia is a de-concentrated state with fiscal centralization. The local governments are still far away from having the political, administrative and fiscal autonomy to manage their own affairs.
\end{abstract}

\section{Оршил}

Өнөө үед төвлөрлийг сааруулах болон төв ба орон нутгийн төсвийн харилцааны асуудал нь дэлхийн улс орнуудын засгийн газрын өөрчлөлт шинэчлэлийн нэн чухал зорилгын нэг болжээ. Нэг талаас төв засгийн газраас үзүүлж буй орон нутгийн үйлчилгээнд сэтгэл хангалуун биш байдал, ардчилалыг хөгжүүлэх, иргэдийн оролцоог нэмэгдүүлэх хэрэгцээ шаардлага, нөгөө талаас төвлөрлийг сааруулснаар нийтийн сангийн хуваарилалтын үр ашиг сайжирч улмаар эдийн засгийн өсөлт нэмэгдэнэ гэдгийг олон тооны судалгаа харуулж буй нь төсвийн эрх мэдлийг сааруулж, нөөцийг орон нутагт шилжүүлэх үндсэн шалтгаан болж байна. Сүүлийн жилүүдэд улс орнууд, ялангуяа хуучин социалист системийн орнууд засгийн газрын чиг үүрэг, төсвийн эрх мэдлийг орон нутагт шилжүүлж төвлөрлийг сааруулахад ихээхэн анхаарч байна. Энэхүү төвлөрлийг сааруулах үйл явцыг НҮБ, Дэлхийн банк зэрэг олон улсын байгууллага идэвхтэй дэмжиж байна.

Манай оронд сүүлийн 20 орчим жил ардчилал, зах зээлийн эдийн засгийн харилцааны шинэ нөхцөлд төрийн үйлчилгээг жигд хүртээмжтэй болгох, төвлөрлийг сааруулж нутгийн өөрийн удирдлагыг бэхжүүлэх, энэ чиглэлээр төсвийн харилцааг шинэчлэх талаар ихээхэн ярьж зарим алхам оролдлогыг хийж байгаа. Гэхдээ энэхүү үйл явц тууштай биш эргэж буцсан, үр дүн багатай, хөгжлийн хандлага нь бүрхэг, алсыг харсан тогтвортой мөрдөх концепц стратегигүй явж ирсэн гэж дүгнэхээр байна. Өнөөдөр төв ба орон нутгийн төсвийн харилцаа болон төвлөрлийг сааруулах асуудалд бусад орны туршлага, өөрийн орны онцлог, шаардлагыг харгалзан нухацтай хандууштай. 
Дэлхийн улс орнууд төвлөрлийг сааруулах янз бүрийн хэлбэрийг хэрэгжүүлж ирсэн бөгөөд орон бүрийн улс төр ба эдийн засгийн бүтэц, газар зүйн байршил, хүн амын нягтрал, соёл, уламжлал зэрэг онцлогоос шалтгаалан төвлөрөл сааруулах нэгдмэл жор гэж байхгүй. Төвлөрлийг сааруулж буй улс орны өмнө тулгарч буй нийтлэг асуудал нь ерөнхий бодлогын хүрээ болон асуудлыг шийдвэрлэх арга хэрэгслийг оновчтой тодорхойлох, бодлогын зөв сонголт хийхэд оршино. Хуучин социалист системийн орнуудын хувьд орон нутгийн засаг захиргааны бүтэц оновчгүй, чиг үүргийн хуваарилалт тодорхойгүй, орон нутагт орлогын бие даасан байдал хангагдаагүй, төсөв хоорондын шилжүүлгийн тогтолцоо тогтворгүй зэрэг төв ба орон нутгийн төсвийн харилцааны сул талууд нь ижил төстэй байгаа юм (Л. Ариунаа, 2007).

\section{Төвлөрөл сааруулах онолын үндэслэл}

Төвлөрөл сааруулах гэдэгт “нөөцийг бүрдүүлэх хуваарилах болон төлөвлөх удирдах чиг үүргийг төв засгийн газар болон агентлагаас түүний орон нутаг дах салбар агентлаг болон доод шатны засаг захиргааны нэгж, төрийн бус байгууллагуудад шилжүүлэхийг" ойлгодог. Гэхдээ орон нутгийн түвшинд бие даан шийдвэр гаргах байдлаар нь нягтралыг багасгах (de-concentration), төлөөлүүлэн гүйцэтгүүлэх (delegation) болон төсвийн төвлөрлийг бүрэн сааруулах (devolution) гэсэн үндсэн 3 хэлбэр байна гэж үздэг. Нягтралыг багасгах нь төрийн чиг үүргийг засаг захиргааны доод шатны нэгжид шилжүүлэх үйл явц бөгөөд жишээ нь, орон нутагт хууль тогтоох болон гүйцэтгэх эрх мэдлийн бие даасан байдал бүрэн болон бүрэн бус хэмжээгээр шилжүүлэхтэй холбоотой тул төвлөрлийг сааруулах нэг хэлбэр мөн. Төлөөлүүлэн гүйцэтгүүлэх тохиолдолд тодорхой чиг үүргийн шийдвэр гаргах бие даасан байдал (legislative sovereignty) нь төв засгийн газартаа байх боловч түүнийг доод шатны нэгж удирдан гүйцэтгэдэг. Харин төсвийн төвлөрлийг бүрэн сааруулах тохиолдолд доод шатны засаг захиргааны нэгж нь хууль тогтоох болон удирдлагын бие даасан байдлаар (administrative sovereignty) хангагдсан байхаас гадна санхүүгийн бие даасан байдлыг нь шийдэж өгдөг. Санхүүгийн бие даасан байдлыг хангах нь татварын суурь болон хувь хэмжээг тогтоох эрх мэдлийг засаг захиргааны тодорхой түвшний нэгжид ямар хэмжээгээр хуваарилах болон засаг захиргааны аль түвшинд орлогын бие даасан байдлыг олгох тухай асуудлыг оновчтой шийдэхэд оршино. Төвлөрөл сааруулах үйл явцын үр нөлөө нь бодит байдалд дээрх 3 хэлбэрийн аль нь эсвэл ямар харьцаатай хослуулан хэрэгжиж байгаагаас ихээхэн хамаарахаас гадна өөрийн орны хувьд төсвийн төвлөрлийн түвшин ямар байхыг тодорхойлох нь нэн чухал.

Зах зээл нь нийтийн бараа үйлчилгээг нийлүүлэх боломжгүй тул төр энэхүү үүргийг хэрэгжүүлдэг бөгөөд энэ нь макро эдийн засгийн тогтворжуулалт, орлого хуваарилалт болон нөөц байршуулах чиг үүргээр хэрэгждэг. Онолын хувьд төв засгийн газар нь улс орны бодлого болон үндэсний хэмжээний үйлчилгээг хүргэх үүргийг хариуцаж харин орон нутгийн засаг нь бүсийн болон орон нутгийн хэмжээний үйлчилгээг иргэддээ хүргэх үүргийг хариуцах нь зүйтэй гэж үздэг. Тиймээс аливаа улс орон төрийн үйлчилгээний талаарх шийдвэрийг төв засгийн газар гаргаж, төвлөрсөн татварын орлогоос санхүүжүүлэх үү, эсвэл орон нутгийн засаг захиргаа сонголтыг хийж, орон нутгийн татвараар санхүүжүүлэх үү гэдгийг шийдэх учиртай. Төрийн үйлчилгээг төвлөрсөн бус байдлаар хүргэх нөхцөлд төв ба орон нутгийн 
төсвийн харилцааны асуудал урган гардаг.

Америкийн эрдэмтэн Тибу (1956) иргэдийн шилжих хөдөлгөөн чөлөөтэй явагдаж буй нөхцөлд засаг захиргааны нэгжүүдийн хооронд төрийн үйлчилгээний хувьд өрсөлдөөнийг нэмэгдүүлснээр үйлдвэрлэлийн үр ашиг сайжирна гэж үзсэн. Иргэдтэй хамгийн ойр байгаа засаг захиргааны нэгж нь оршин суугчдынхаа сонирхол, сонголт болон зардлын талаар илүү мэдээлэлтэй байдаг(Оатис, 1972). Тэгэхээр хамгийн сайн мэдээлэлтэй буй засаг захиргааны нэгж нь тухайн үйлчилгээг иргэдэд хүргэснээр нөөц байршуулалт илүү үр ашигтай болно. Тиймээс төсвийн төвлөрлийг сааруулснаар орон нутгийн засаг захиргааны хооронд нийтийн барааны нийлүүлэлтийн хувьд өрсөлдөөн нэмэгдэж, төсвийн хэт өргөжилт хязгаарлагдах, мөн хяналт болон хариуцлагын тогтолцоо сайжирснаар орон нутгийн хувьд нийтийн үйлчилгээг иргэдэд үр ашигтайгаар хүргэж, зах зээлийн үйл ажиллагааг дэмжин эдийн засгийн өсөлтийг нэмэгдүлнэ.

Гэхдээ орон нутгийн улс төрчид зарлагын хэмжээг хэт өсгөх, бусад орон нутгийн зардлаар өөрийн нутаг дэвсгэрт үзүүлэх үйлчилгээг нэмэгдүүлэх зэрэг сонирхолт байдаг. Тиймээс төвлөрөл сааруулах хэлбэрийг зөв сонгох нь нэн чухал. Жишээ нь төвлөрлийг сааруулснаар орон нутаг өөрийн татвараар санхүүжиж байвал төсөв хэмнэгддэг, харин төв засгийн газраас олгох шилжүүлгээр санхүүжиж байвал зардал улам нэмэгдэх хандлагатай байдаг. Тэгэхээр төвлөрөл сааруулсны үр дүн нь төрийн санхүүгийн институцын бүтцээс маш их хамааралтай юм. Төвлөрлийг үр дүнтэй сааруулахын тулд юуны өмнө чиг үүргийн болон орлогын хуваарилалт, төсөв хоорондын шилжүүлгийн тогтолцоо, орон нутгийн зээлэг болон төрийн өмчит үйлдвэрийн газрын удирдлага зэргийг хамарсан төсвийн харилцааны зөв оновчтой тогтолцоог бүрдүүлэх хэрэгтэй.

Төвлөрөл сааруулах үйл явц нь тухайн орны онцлог нөхцлийг харгалзан үзсэн нэгдмэл стратегиар хэрэгжсэн нөхцөлд л эерэг үр дүнд хүрнэ. Харин нэгдмэл стратегигүй, буруу бодлогоор хэрэгжүүлж алдаа гаргавал хязгаарлагдмал нөөцийн хяналт алдагдаж өргөжилтийн үр ашиг гарахгүй байх, тэрчлэн төрийн үйлчилгээ үр дүн муутай байх, бодлогын зохицуулалт ээдрээтэй болох зэрэг сөрөг үр дагаврууд гардаг. Ер нь хөгжиж буй орны хувьд төрийн үйлчилгээ нь иргэдийн сонирхол, сонголтыг хангах гэхээсээ илүү анхан шатны хэрэгцээг хангахад чиглэдэг, түүнчлэн иргэдийн сонголтод хувийн, гэр бүлийн болон намын нөлөө их байдаг тул ардчилсан сонгуулийн үр дүнд төрийн үйлчилгээний эрэлт үнэн зөв тодорхой-логдох боломж нэн бага байдаг. Ерөнхийдээ бүс нутаг, хотуудад эдийн засгийн хөгжил нь жигд бус, ихээхэн ялгаатай, нөгөө талаас дэлхийн зах зээлийн үнийн өөрчлөлт, байгалийн хүчин зүйл зэргээс төсөв, эдийн засаг нь ихээхэн хамааралтай, байнгын өндөр инфляцтай, мөн орон нутгийн захиргааны чадавх сул улс оронд эхний ээлжинд тогтворжилтыг хангах зорилгоор татвар болон зарлагыг төвлөрүүлэн зохицуулах нь зохистой гэж зарим эрдэмтэд үздэг. Төвлөрлийг сааруулах нь бүхнийг анагаагч эм биш бөгөөд төвлөрөх ба эс төвлөрөхийн аль нэгийг сонгох бус зөвхөн өөрийн орны нөхцөл байдалд тохирсон зөв тогтолцоог бүрдүүлэх нь чухал юм.

\section{Манай орны өнөөгийн байдал}

Монгол улс нь бусад шилжилтийн эдийн засагтай орны нэгэн адил төрийн үйлчилгээний талаар шийдвэр гаргалт, удирдлага болон санхүүжилт хэт төвлөрсөн тогтолцоотой байсан. Манай оронд явагдсан төвлөрлийг сааруулах 
чиглэлийн өөрчлөлт шинэчлэл нь дээрээс доош чиглэлээр нэгдмэл стратегигүй маш удаашралтай хэрэгжиж ирлээ. Төрийн захиргааны шинэчлэлийн хүрээнд авч хэрэгжүүлсэн удаа дараагийн арга хэмжээний дүнд Монгол улс нь нягтралыг багасгасан төсвийн төвлөрөл бүхий орон болсон. Энэ нь ДНБ болон төсвийн зарлагын харьцааны үзүүлэлтээс зураг $1 \backslash$ харагдаж байна.

Зураг 1-д харуулснаар 2000-2002 онд дунджаар ДНБ-д орон нутгийн төсвийн зарлагын эзлэх хувь 10-15\% байснаа 2003 оноос 3\% орчим болж огцом буурсан байна. Тиймээс 2003 оноос манай оронд төвлөрөх үйл явц эхэлсэн гэж дүгнэж болно. Үүний гол шалтгаан нь төрийн үйлчилгээний үр ашиг, үр дүнг сайжруулах, чиг үүргийг тодорхой болгох зорилгоор 2003 онд төсвийн байгууллагын удирдлага, санхүүжилтийн тухай хууль ІТБУСТХІ хэрэгжиж эхэлсэн, мөн үүнтэй зэрэгцэн төрийн сангийн нэгдсэн тогтолцоог нэвтрүүлсэнтэй холбоотой юм.

Зураг 1. ДНБ-д төсвийн зарлагын эзлэх хувь, 2000-2009

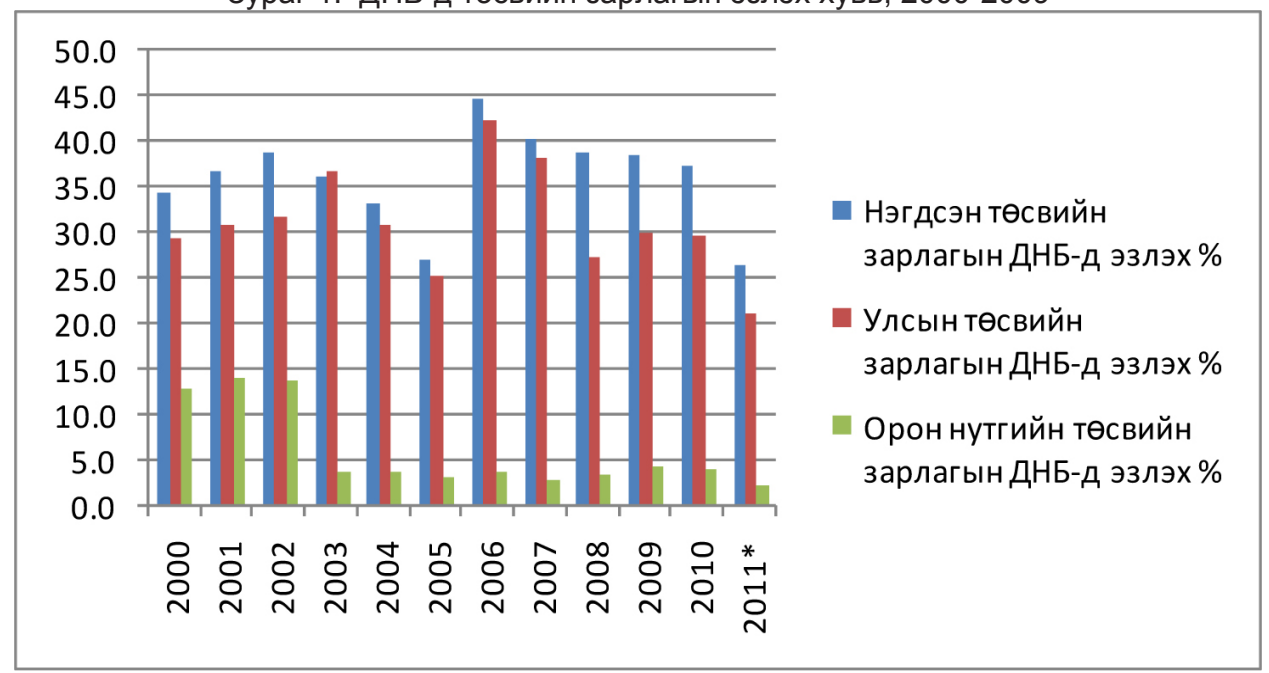

Эх сурвалж: Сангийн яамнаас гаргасан тоо баримтад үндэслэн тооцов, 2000-2010.

Төсвийн төвлөрлийг сааруулах үйл явцыг үр дүнтэй болгохын тулд орон нутаг өөрийн орлогын эх үүсвэрийг хянах эрх мэдэлтэй байх шаардлагатай байдаг. Орлогын бие даасан эх үүсвэргүй орон нутаг нь үргэлж төв засгийн газраас санхүүгийн хувьд хараат байдаг. Тэгэхээр орлогын ямар эх үүсвэрийг орон нутагт хуваарилж, түүнийг хэрхэн хэрэгжүүлэх асуудал буюу “татвар хуваарилах асуудлыг” чиг үүргийн хуваарилалттай нягт уялдаатай шийдэх учиртай. Энэ асуудлыг шийдэхдээ чие үүргийг санхүүжилт дагана гэсэн үндсэн зарчимыг баримтлах нь зүйтэй.

Онолын хувьд эдийн засгийг тогтворжуулах болон орлого эд баялагийг хуваарилахад нөлөөлдөг аж ахуйн нэгжийн болон хүн амын орлогын албан татвар, ашигт малтмалын татварыг төв засгийн газарт, харин харьцангуй тогтвортой суурь бүхий татвар, хураамжийг төрийн үйлчилгээнээс хүртэх ашиг тусаар нь баримжаалж орон нутагт хуваарилах зүйтэй гэж үздэг. Жишээлбэл, үл хөдлөх хөрөнгийн татвар, авто тээврийн болон өөрөө явагч хэрэгслийн татвар нь орон нутгийн татвар байдаг. 
Төсвийн нийт орлогын ДНБ-д эзлэх хувь хэмжээ 2000 онд 33,4\% байсан бол улмаар 2008 онд 43,7\%, 2010 онд 37,8\% болон өссөн бол орон нутгийн орлогын ДНБ-д эзлэх хувь хэмжээ 6,5\% байсан нь 2008 онд 2,8\% хүртэл буурчээ. Орон нутгийн орлогын нийт орлогод эзлэх хувь 2000 онд 19,2\% байсан бол 2008 онд $6,4 \%$ болтол буурч ижил динамикаар өөрчлөгдсөн байна. Мөн орон нутгийн зарлага ба орон нутгийн орлогын харьцаа 2000 онд 196,8\% байсан бол 2008 онд 127,7\% болж буурсан нь ТБУСТ хуулиар нийгмийн үндсэн үйлчилгээ үзүүлэх чиг үүргийг харьяалах яаманд шилжүүлсэнтэй холбоотой юм.

Хүснэгт 1.

Орон нутгийн орлогын ДНБ болон нийт зарлагад эзлэх хувь хэмжээ, 2000-2009

\begin{tabular}{|l|c|c|c|c|c|c|c|c|c|c|c|}
\hline & 2000 & 2001 & 2002 & 2003 & 2004 & 2005 & 2006 & 2007 & 2008 & 2009 & 2010 \\
\hline $\begin{array}{l}\text { Нийт орлого/ } \\
\text { ДНБ, \% }\end{array}$ & 33.4 & 37.2 & 37.9 & 36.8 & 36.3 & 36.7 & 34.5 & 39.4 & 43.7 & 37.7 & 37.8 \\
\hline $\begin{array}{l}\text { Орон нутгийн } \\
\text { орлого/ДНБ, \% }\end{array}$ & 6.5 & 7.6 & 8.4 & 3.2 & 3.1 & 3.1 & 2.3 & 2.8 & 2.8 & 3.9 & 4.4 \\
\hline $\begin{array}{l}\text { Орон нутгйн } \\
\text { орлого/нийт } \\
\text { орлого, \% }\end{array}$ & 19.2 & 20 & 21.6 & 8.6 & 8.4 & 8.5 & 6.4 & 6.9 & 6.4 & 10.4 & 15.4 \\
\hline $\begin{array}{l}\text { Орон нутгийн } \\
\text { зарлага/орон } \\
\text { нутгийн орлого, \% }\end{array}$ & 196.8 & 183.4 & 161.1 & 105.4 & 115.4 & 111.8 & 109.4 & 106.7 & 127.7 & 100.8 & 67.7 \\
\hline
\end{tabular}

Эх сурвалж: Сангийн яамнаас гаргасан тоо баримтад үндэслэн тооцов, 2000-2010.

Зураг 2. Орон нутгийн татварын орлогын бүтэц, 2007 он, (хувиар)

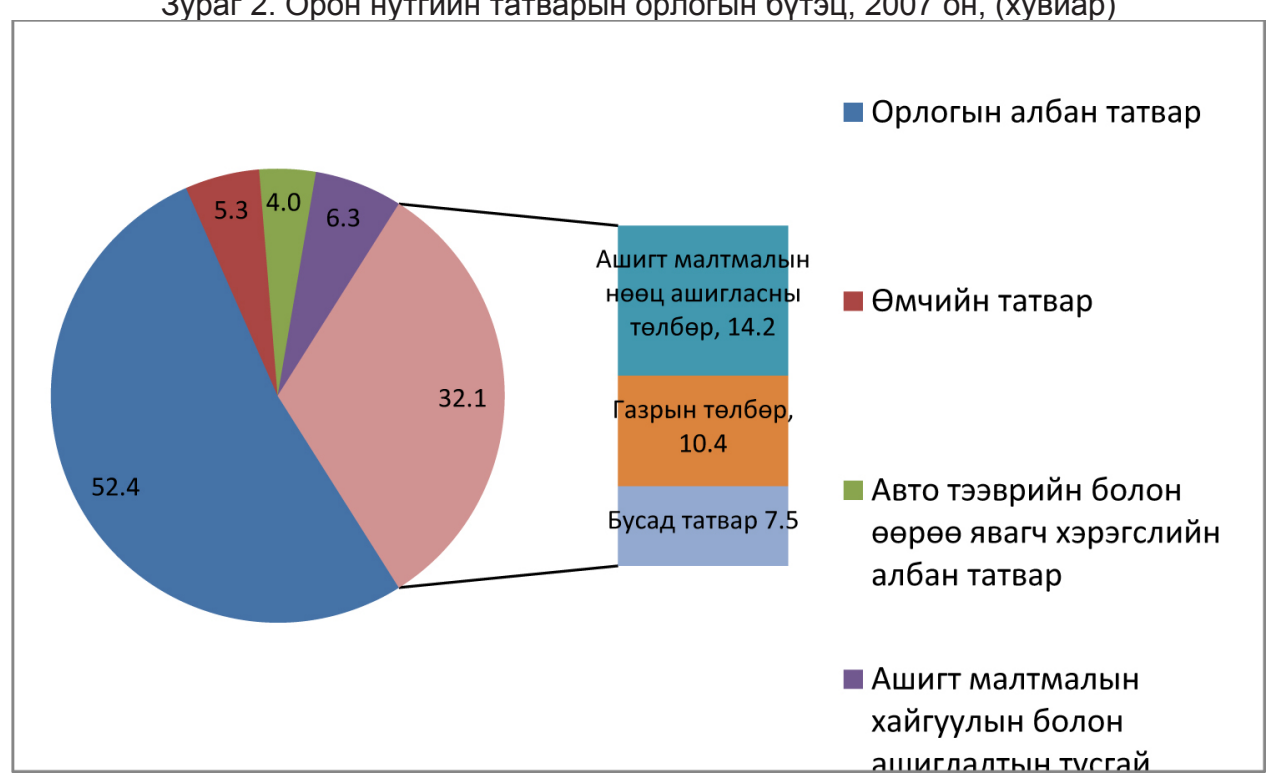

Эх сурвалж: Сангийн яамнаас гаргасан тоо баримт ашиглан тооцов.

2009 оны байдлаар орон нутгийн татварын орлогын 52,4\% хүн амын орлогын татвар, 15,6\% өмчийн татвар, авто тээврийн болон өөрөө явагч хэрэгслийн татвар болон ашигт малтмалын хайгуулын болон ашиглалтын тусгай зөвшөөрлийн 
төлбөр зэргийн орлогоос, үлдсэн 32,1\% бусад татвар, хураамжаас бүрдэж байна. Одоогийн үйлчилж буй хууль эрх зүйн тогтолцооны дагуу цалин түүнтэй адилтгах орлогын татвараас бусад орлого сайн бүрдүүлдэг татварыг улсын төсөвт, харин орлого бага төвлөрүүлдэг татвар, хураамж нь орон нутагт хуваарилагдсан байна. Тиймээс орон нутаг нь өөрийгөө санхүүжүүлэх чадвар муутай, улсын төсвөөс авах санхүүгийн дэмжлэгээс ихээхэн хамааралтай, өөрөөр хэлбэл төсвийн хувьд орон нутаг бие даасан бус төв засгийн газраас хараат байна.

\section{Дүгнэлт}

Орон нутаг зарлагаа санхүүжүүлэхэд хангалттай хэмжээний өөрийн орлого бүрдүүлэх чадваргүй, шаардлагатай төрийн үйлчилгээг засаг захиргааны бусад нэгж, төв засгийн газраас санхүүгийн дэмжлэг үзүүлэх замаар нийлүүлж буй өнөөгийн нөхцөлд орон нутгийн бие даасан байдал, орлого төвлөрүүлэх идэвх сонирхлыг дэмжихийн тулд төвлөрлийг сааруулах арга хэмжээний хүрээнд юуны өмнө тэнцвэржүүлэх шилжүүлгийн хуваариалтыг тогтвортой, ил тод, таамаглаж болохуйц томьёогоор хуваарилдаг болох нь зүйтэй (Л.Ариунаа, 2010).

Улс орны хөгжлийн өнөөгийн шатанд ялангуяа уул уурхай, ашигт малтмал, түүнийг тойрсон дэд бүтцийн хөгжлийг даган бүс нутгийн хөгжил, түүний эдийн засгийн чадавхид ихээхэн өөрчлөлт гарахаар байна.Төвлөрлийг сааруулах, төсвийн харилцааны хувьд өнгөрсөн хугацааны ололт, алдаандаа бодитой дүн шинжилгээ хийн судлаач мэргэжилтнүүдээ оролцуулсны үндсэн дээр хөгжлийнхөө хандлагыг харгалзаж алсыг харсан, бодитой хэрэгжин тогтвортой мөрдөгдөх концепц боловсруулан гаргаж эрх зүйн орчинг бүрдүүлэх шаардлагатай байна.

\section{Ном зуй}

1. Ariunaa, L. (2007) Status Quo on Fiscal Decentralization in Mongolia. Discussion Paper 54, Chair of Public Economics, Potsdam University. Potsdam.

2. Ariunaa, L. (2010) Fiscal Federalism and Decentralization in Mongolia. Universitaetsverlag Potsdam.

3. Oates, W.E. (1972) Fiscal Federalism. 3d ed. Aldershop, Gregg Revivals.

4. Tiebout, C.M. (1956) A Pure Theory of Local Government Expenditure. Journal of Political Economy, 64 (5) October, pp. 416-426. 